\title{
Prevalence of pain among melanoma patients
}

\author{
Prevalência de dor em pacientes com melanoma
}

Fernanda Cardoso Parreiras ${ }^{1}$, Alberto Julius Alves Wainstein 1 , Márcia Morete ${ }^{2}$, Lara Salvador Géo³

DOI 10.5935/1806-0013.20160010

\section{ABSTRACT}

BACKGROUND AND OBJECTIVES: The incidence of malignant melanoma is increasing worldwide. This is a tumor with high morbidity and mortality. Most common symptom of cancer patients is pain, which is complex, multifactorial and directly impacts patients' quality of life. However, there is little information about the prevalence of pain in this population. This study aimed at observing the prevalence of pain among melanoma patients in a reference center, in addition to obtaining information about treatments and pain-related incapacity.

METHODS: Descriptive, retrospective, exploratory study level I, with quantitative approach, carried out by means of the analysis of 306 medical records of melanoma patients.

RESULTS: The prevalence of pain was $38.2 \%$. Among those with pain complaints, its location was the same as the injury in $20.5 \%$ of cases, in $8 \%$ of cases it was at the same site of malignant melanoma metastases and $55.8 \%$ have stated that pain was related to lymphadenectomy. Among such patients, $70 \%$ were treated to control pain, $2 \%$ were referred to specialized treatment and $75 \%$ have reported pain-related incapacity.

CONCLUSION: Persistent pain is a prevalent and disabling melanoma-related symptom which is related both to the surgical procedure and the staging, requiring early prevention and treatment actions.

Keywords: Melanoma, Pain, Prevalence.

\section{RESUMO}

JUSTIFICATIVA E OBJETIVOS: O melanoma maligno vem aumentando a sua incidência em todo o mundo; trata-se de uma neoplasia com elevada morbidade e mortalidade. O sintoma mais comum em pacientes com câncer é a dor, que é complexa, multifatorial e impacta diretamente a qualidade de vida dos pacientes. No entanto, há poucas informaçóes sobre a prevalência

1. Faculdade de Ciências Médicas de Minas Gerais, Belo Horizonte, MG, Brasil.

2. Hospital Albert Einstein, Instituto de Ensino e Pesquisa, Săo Paulo, SP, Brasil.

3. Pontifícia Universidade Católica de Minas Gerais, Belo Horizonte, MG, Brasil.

Submitted in August 27, 2015.

Accepted for publication in January 20, 2016.

Conflict of interests: none - Sponsoring sources: none.

\section{Correspondence to:}

Fernanda Cardoso Parreiras

Rua Matias Cardoso 129, 8 A, Bairro Santo Agostinho

30170-050 Belo Horizonte, MG, Brasil.

E-mail: fernanda.med@me.com

(C) Sociedade Brasileira para o Estudo da Dor de dor nessa população. O objetivo deste estudo foi observar a prevalência de dor em pacientes portadores de melanoma em um serviço de referência, além de obter informações a respeito dos tratamentos e sobre a incapacidade relacionada à dor.

MÉTODOS: Estudo descritivo, retrospectivo, exploratório de nível I, com abordagem quantitativa, realizado por meio da análise de 306 prontuários de pacientes portadores de melanoma. RESULTADOS: A prevalência de dor foi de 38,2\%. Dentre os que se queixavam de dor, sua localização era a mesma da lesão em 20,5\% dos casos, em $8 \%$ dos casos ela era no mesmo local das metástases do melanoma maligno e 55,8\% responderam que a dor relacionava-se com a linfadenectomia. Dentre esses pacientes, $70 \%$ receberam tratamento para o controle da dor, $2 \%$ foram encaminhados para tratamento especializado e $75 \%$ relataram incapacidade relacionada à dor.

CONCLUSÃO: Dor persistente é um sintoma prevalente e incapacitante relacionado ao melanoma que se relaciona tanto com o procedimento cirúrgico quanto com o estadiamento, o que exige ações de prevenção e tratamento precoce.

Descritores: Dor, Melanoma, Prevalência.

\section{INTRODUCTION}

Malignant melanoma is an aggressive tumor, the incidence of which is increasing worldwide. In the United States, it is estimated that 2015 shall have 73870 new cases of the disease and approximately 9940 deaths by melanoma ${ }^{1}$.

In Brazil, population-base data do not express the reality of the problem, especially when data such as pain are required ${ }^{2,3}$. In the same proportion that the incidence of melanoma increases, it is expected that related problems might be underestimated and undertreated. It is known that cancer pain is complex and multifactorial and is called "Total Pain" for involving different pathophysiological factors (nociceptive and neuropathic pain) in addition to being associated to the whole dimension of suffering. This feature is very clear in melanomas because they are tumors with high mortality rates and affecting different organs, especially skin, directly interfering with patients' self-image. It may evolve with cancer wounds and consequently social isolation, solitude and fear. All these aspects are directly related to the complexity of melanoma patients' pain $^{5-7}$.

The etiology of melanoma pain may be associated to different factors, such as the presence of an injury, local inflammatory reactions in tumor or other tissues and chronic compression of adjacent tissues. It may also be related to treatment, chemotherapy, surgical injury resection, sentinel lymph node 
biopsy, limphadenectomy, consequent edema, isolated limb perfusion and metastases. However, all these factors will be inevitably related to psychosocial aspects and to the impact of the disease on quality of life (QL) of such patients ${ }^{8,9}$.

Chronic pain induced by surgical procedures associated to the treatment of melanoma is also poorly known. In general, patients are submitted to primary or metastatic injuries biopsy to establish the diagnosis, enhance safety margins, sentinel lymph node biopsy (SLNB) to evaluate lymph node spread and/or to perform limphadenectomy according to the state of the studied chain. In addition, in some cases, subsequent procedures are indicated for resection and biopsy of recurrences or metastases; there are also palliative procedures such as isolated limb perfusion, which are used to control the disease. However, there are no epidemiological data to favor a more effective approach and more effective measures to prevent pain during all treatment stages for this population ${ }^{10,11}$. Considering the relevance of this disease for the world population and the importance of its pain, we felt the need to develop this study aiming at knowing the prevalence of pain in melanoma patients of a reference service, at identifying the frequency with which such patients are treated and referred to specialized treatment, as well as at establishing the relationship of pain and melanoma.

\section{METHODS}

This is a descriptive, retrospective study with quantitative approach, carried out by documental means (medical charts). We have evaluated 306 medical charts of melanoma patients during 2014 and first trimester of 2015. Absolute and relative frequencies were calculated for all variables, confidence interval of $95 \%$ was calculated for prevalence of pain ${ }^{12}$, and to observe the association between pain complaint and staging Fisher Exact test ${ }^{12}$ was used and respective odds ratio was calculated $^{12}$.

Inclusion criteria were patients with malignant melanoma being followed up by the above-mentioned reference service and under treatment until 2014.

A form with data extracted from patients' medical records was used for data collection. The form is made up of data regarding patients' identification, such as age and gender, and data such as diagnostic time, presence or not of pain, pain location and treatment and referral to specialized pain service.

This study was approved by the Ethics Committee, Hospital Israelita Albert Einstein, CAAE 44165315.8.3001.5134/2015.

\section{RESULTS}

Major prognostic factor for melanoma is staging, which depends on the depth of primary injury invasion or thickness (Breslow), of lymph node involvement and of the presence of distant metastasis. To control these factors during diagnosis and treatment, patients may be submitted to primary injury biopsy, resection or increasing of margins, study of the lymph node chain with SLNB and lymphadenectomy in cases of positive SLNB (with the presence of malignant cells) or clinically palpable lymph nodes with suspected neoplastic involvement. Other metastasis resections or metastasectomies may be indicated in addition to chemotherapy, radiotherapy and immunetherapy for advanced cases. All this process may be more or less associated to pain.

As from the descriptive analysis of all study variables (Table 1) it is observed that among melanoma patients the prevalence of pain is $38.2 \%$; however, with $95 \%$ confidence interval, the interval for the prevalence of pain goes from 32.7 to $43.6 \%$ (Figure 1).

Table 1. Descriptive analysis of all study variables

\begin{tabular}{|c|c|c|c|}
\hline Questions & Answer & $\mathrm{n}$ & $\%$ \\
\hline \multirow[t]{2}{*}{ Pain complaint } & No & 189 & 61.8 \\
\hline & Yes & 117 & 38.2 \\
\hline \multirow{2}{*}{$\begin{array}{l}\text { Is pain location the same of the } \\
\text { primary injury (malignant mela- } \\
\text { noma? }\end{array}$} & No & 93 & 79.5 \\
\hline & Yes & 24 & 20.5 \\
\hline \multirow{2}{*}{$\begin{array}{l}\text { Is pain location the same as the } \\
\text { malignant melanoma metasta- } \\
\text { sis? }\end{array}$} & No & 108 & 92.3 \\
\hline & Yes & 9 & 7.7 \\
\hline \multirow{2}{*}{$\begin{array}{l}\text { Pain location is related to ma- } \\
\text { lignant melanoma? }\end{array}$} & No & 21 & 18.1 \\
\hline & Yes & 95 & 81.9 \\
\hline \multirow{3}{*}{$\begin{array}{l}\text { Relation of pain with lymph } \\
\text { node resection }\end{array}$} & SLNB & 8 & 8.4 \\
\hline & Lymphadenectomy & 53 & 55.8 \\
\hline & None of the above & 34 & 35.8 \\
\hline \multirow{2}{*}{$\begin{array}{l}\text { Were you informed about pain } \\
\text { treatment? }\end{array}$} & No & 35 & 29.9 \\
\hline & Yes & 82 & 70.1 \\
\hline \multirow{2}{*}{$\begin{array}{l}\text { Were you informed about spe- } \\
\text { cialized treatment (pain clinic)? }\end{array}$} & No & 115 & 98.3 \\
\hline & Yes & 2 & 1.7 \\
\hline \multirow{2}{*}{$\begin{array}{l}\text { Report of pain-related incapa- } \\
\text { city? }\end{array}$} & No & 29 & 24.8 \\
\hline & Yes & 88 & 75.2 \\
\hline \multirow[t]{5}{*}{ Staging } & 1 & 81 & 26.5 \\
\hline & II & 55 & 18.0 \\
\hline & III & 74 & 24.2 \\
\hline & IV & 38 & 12.4 \\
\hline & Tis & 58 & 19.0 \\
\hline
\end{tabular}

SLNB = sentinel lymph node biopsy; Tis = tumor in situ.

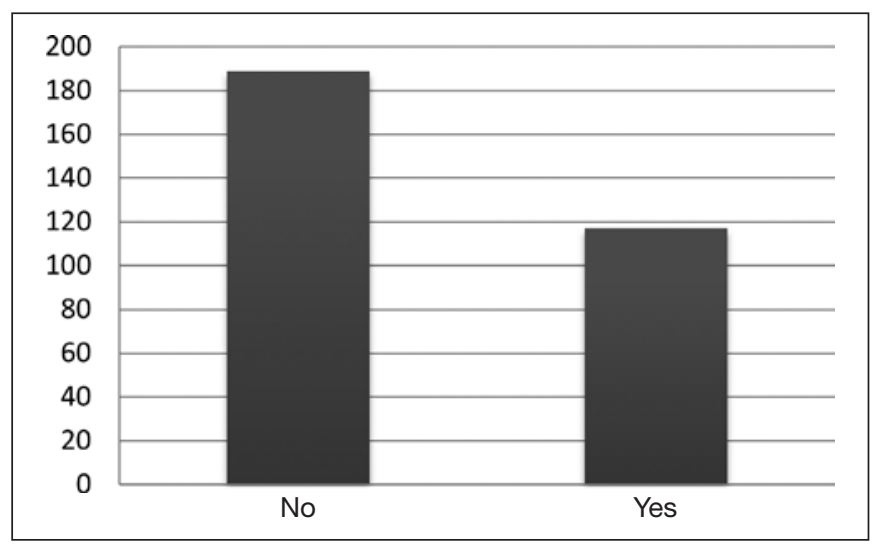

Figure 1. Pain complaint among studied patients 


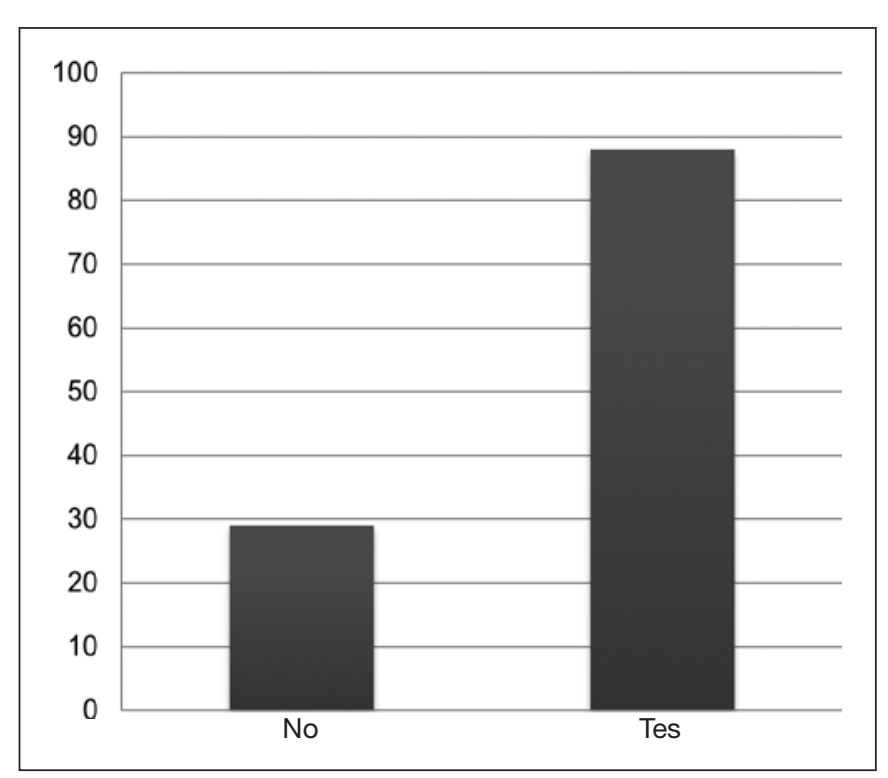

Figure 2. Pain-related incapacity report

Among those with pain $(\mathrm{n}=117)$, its location was the same as of the injury in $20.5 \%$ of cases and was essentially related to primary injury resection of to local recurrences; in $8 \%$ of cases pain was in the same site of malignant melanoma metastases, $55.8 \%$ of patients answered that pain was related to limphadenectomy performed after the identification of positive sentinel lymph node or was related to the lymph node identified at clinical evaluation, and $8.4 \%$ have related it to SLNB.

Among these patients, 70\% were treated for pain control, 2\% were referred to specialized treatment and $75 \%$ have reported pain-related incapacity.

With regard to staging, $26.5 \%$ are in stage I, $18.0 \%$ in stage II, $24.2 \%$ in stage III and $12.4 \%$ in stage IV, being that $18.9 \%$ are in the in situ stage (Tis). The analysis of significant association $(\mathrm{p}=0.000)$ between pain and staging level (Table 2) shows that the chance of pain complaint for stage II individuals is 17.04 (5.44 to 83.85) times the chance of pain complaint for stage I individuals; the chance of pain complaint for stage III individuals is 89.84 (28.58 to 444.74 ) times the chance of pain complaint for stage I individuals; the chance of pain complaint for stage IV individuals is 230.42 (60.69 to 1714.31) times the chance of pain complaint for stage I individuals; pain complaint was statistically significant when comparing stage I and Tis.

\section{DISCUSSION}

Pain is a prevalent and disabling cancer-related symptom ${ }^{13}$. Persistent postoperative pain, including surgeries for cancer treatment, is a very common symptom ${ }^{13,14}$. Among causes of pain in this group of patients, highest prevalence is related to lymphadenectomy, which is a procedure with high morbidity rate, and other studies are being carried out to define the real benefit of this procedure ${ }^{14,15}$. Neuss et al. ${ }^{15}$ have studied 111 patients with melanoma after axillary lymphadenectory and have found high prevalence of pain in this group, which was directly associated to postoperative incapacity, confirming our study results. So, there is the need for better care and pain treatment protocols for patients submitted to this procedure.

It on one side pain was related to surgical procedure, it was also clear that pain prevalence increased according to staging, being worse in stages III and IV patients, showing the increasing need for specific care to patients with advanced disease.

\section{CONCLUSION}

Further studies are needed to establish the reality lived by melanoma patients, however, it has been shown the need for an early globalized assistance, starting at diagnostic time, but not forgetting the need to follow up and attention to those in more advanced stages of the disease. The objective is to provide better care, better control and better quality of life to this population.

\section{REFERENCES}

1. American Cancer Society. Cancer Facts \& Figures. Atlanta: American Cancer Society; 2015. http://www.cancer.org/research/cancerfactsstatistics/cancerfactsfigures2015.

2. Fernandes NC, Calmon R, Maceira JP, Cuzzi T, Silva CS. Melanoma cutâneo: estudo prospectivo de 65 casos. An Bras Dermatol. 2005;80(1):25-34.

3. Maia M, Russo C, Ferrari N, Ribeiro MC, Santos AB. Reflexốes em relaçáo à epidemiologia do melanoma cutâneo no Brasil. An Bras Dermatol. 2002;77(2):163-70.

4. Estimativa de Câncer no Brasil 2014 , www.inca.gov.br/estimativa/2014

5. McPherson CJ, Hadjistavropoulos T, Devereaux A, Lobchuk MM. A qualitative investigation of the roles and perspectives of older patients with advanced cancer and their caregivers in managing pain in the home. BMC Palliative Care 2014;13:39.

6. Lee YJ, Hyun MK, Jung JY, Kang MJ, Keam B, Go SJ. Effectiveness of education interventions for management of cancer pain: a systematic review. Asian Pac J Cancer Prev. 2014;15(12),4787-93

7. Loquai C, Scheurich V, Syring N, Schmidtmann I, Rietz S, Werner A, et al. Screening for distress in routine oncological care-a survey in 520 melanoma patients. PloS One. 2013;8(7):e66800.

Table 2. Comparison between pain complaint and staging level

\begin{tabular}{|c|c|c|c|c|c|c|c|}
\hline \multirow[t]{2}{*}{ Staging } & \multicolumn{4}{|c|}{ Pain complaint } & \multirow[t]{2}{*}{$p$ value } & \multirow[t]{2}{*}{ OR } & \multirow[t]{2}{*}{$\mathrm{Cl}-95 \%$} \\
\hline & & & & & & & \\
\hline I & 79 & $97.5 \%$ & 2 & $2.5 \%$ & 0.000 & 1.00 & - \\
\hline II & 33 & $60.0 \%$ & 22 & $40.0 \%$ & & 17.04 & [5.44; 83.85] \\
\hline III & 16 & $21.6 \%$ & 58 & $78.4 \%$ & & 89.84 & {$[28.58 ; 444.7]$} \\
\hline IV & 3 & $7.9 \%$ & 35 & $92.1 \%$ & & 230.42 & {$[60.69 ; 1714.3]$} \\
\hline Tis & 58 & $100.0 \%$ & 0 & $0.0 \%$ & & 0.30 & {$[0.01 ; 5.77]$} \\
\hline
\end{tabular}


8. Høimyr H, von Sperling ML, Rokkones KA, Stubhaug A, Finnerup K, Jensen TS, et al. Persistent pain after surgery for cutaneous melanoma. Clin J Pain. 2012;28(2):149-56.

9. Winstanley JB, White EG, Boyle FM, Thompson JF. What are the pertinent quality-oflife issue for melanoma cancer patients? Aiming for the development of a new module to accompany the EORTC core questionnaire. Melanoma Res. 2013;23(2):167-74.

10. Garbe C, Eigentler TK. Diagnosis and treatment of cutaneous melanoma: state of the art 2006. Melanoma Res. 2007;17(2):117-27.

11. Schadendorf D. Is there a standard for the palliative treatment of melanoma? Onkolo- gie. 2002;25(1):74-6.

12. Agresti A. Categorial data analysis. $3^{\text {th }}$ ed. New York: Wiley; 2002. 5-17p.

13. de Vries M, Hoekstra HJ, Hoekstra-Weebers JE. Quality of life after axillary or groin sentinel lymph node biopsy, with or without completion lymph node dissection, in patients with cutaneous melanoma. Ann Surg Oncol. 2009;16(10):2840-7.

14. Elliott AM, Torrance N, Smith BH, Lee AJ. Is chronic pain associated with subsequent cancer? A cohort record linkage study. Eur J Pain. 2010;14(8):860-3.

15. Neuss H, Koplin G, Haase O, Reetz C, Mall JW. Preemptive analgesia reduces pain after radical axillary lymph node dissection. J Surg Res. 2010;162(1):88-94. 